Article

\title{
Carbon Emissions Constrained Energy Planning for Aluminum Products
}

\author{
Rok Gomilšek ${ }^{1,2}$, Lidija Čuček ${ }^{2, * \mathbb{D}}$, Marko Homšak ${ }^{3}$, Raymond R. Tan ${ }^{4}$ and Zdravko Kravanja ${ }^{2}$ \\ 1 Talum Inštitut d.o.o., Tovarniška cesta 10, SI-2325 Kidričevo, Slovenia; rok.gomilsek@talum.si \\ 2 Faculty of Chemistry and Chemical Engineering, University of Maribor, Smetanova ulica 17, \\ SI-2000 Maribor, Slovenia; zdravko.kravanja@um.si \\ 3 Talum d.d., Tovarniška cesta 10, SI-2325 Kidričevo, Slovenia; marko.homsak@talum.si \\ 4 Chemical Engineering Department, De La Salle University, 2401 Taft Avenue, Manila 0922, Philippines; \\ raymond.tan@dlsu.edu.ph \\ * Correspondence: lidija.cucek@um.si; Tel.: +38-622-294-454
}

Received: 26 April 2020; Accepted: 22 May 2020; Published: 1 June 2020

\begin{abstract}
The production of primary aluminum is an energy-intensive industry which produces large amounts of direct and indirect greenhouse gas emissions, especially from electricity consumption. Carbon Emissions Constrained Energy Planning proved to be an efficient tool for reducing energy-related greenhouse gas emissions. This study focuses on energy planning constrained by $\mathrm{CO}_{2}$ emissions and determines the required amount of $\mathrm{CO}_{2}$ emissions from electricity sources in order to meet specified $\mathrm{CO}_{2}$ emission benchmark. The study is demonstrated on and applied to specific aluminum products, aluminum slugs and aluminum evaporator panels. Three different approaches of energy planning are considered: (i) an insight-based, graphical targeting approach, (ii) an algebraic targeting approach of cascade analysis, and (iii) an optimization-based approach, using a transportation model. The results of the three approaches show that approximately $2.15 \mathrm{MWh}$ of fossil energy source should be replaced with a zero-carbon or 2.22 MWh with a low-carbon energy source to satisfy the benchmark of $\mathrm{CO}_{2}$ emissions to produce $1 \mathrm{t}$ of aluminum slug; however, this substitution results in higher costs. This study is the first of its kind demonstrated on and applied to specific aluminum products, and represents a step forward in the development of more sustainable practices in this field.
\end{abstract}

Keywords: $\mathrm{CO}_{2}$ emissions; electricity planning; $\mathrm{CO}_{2}$ Constrained Energy Planning (CCEP); approaches for CCEP; aluminum products

\section{Introduction}

The current increase in global greenhouse gas (GHG) emissions should be substantially reversed to mitigate climate change and prevent global temperatures from rising beyond the $2{ }^{\circ} \mathrm{C}$ target [1]. Currently, global GHG emissions are attributed mainly to energy (more than $70 \%$ of GHG emissions), while the remaining are due to agriculture, land-use change and forestry, and industrial processes and waste [2]. In the European Union (EU), a binding target has been set to reduce GHG emissions by at least $40 \%$ by 2030 compared to 1990 levels [3].

In the EU, energy-intensive industries including iron, steel, cement and aluminum either have to pay carbon taxes or, if they are included in the EU's Emissions Trading System (EU ETS), they need to have sufficient allowances to cover all emissions produced [4]. Under EU ETS, installations could receive free allocation allowances every year and/or buy (remaining) emission allowances on the market. Every year, aluminum producers in the EU receive some allowances allocated for free, owing to international competitiveness of carbon leakage [5]. The number of free allocations is being decreased 
gradually each year, with the goal of reducing emissions and stimulating companies to invest in the transition to low-carbon technologies [4].

Aluminum (or aluminium in British spelling) is the second most used metal in the world after iron. The production of aluminum is a highly energy-intensive process, with electricity representing a large share of the energy consumed. The industry accounts for 3.5\% of global electricity consumption [6]. Consequently, the aluminum industry produces a large amount of direct and especially indirect GHG emissions. During electrolysis, primary aluminum is produced via the reduction of alumina $\left(\mathrm{Al}_{2} \mathrm{O}_{3}\right)$; this alumina is, in turn, refined from bauxite (aluminum ore). According to the data from the International Aluminum Institute [6], on average, 14.22 MWh of electricity was used to produce $1 \mathrm{t}$ of primary aluminum in 2019.

Electricity can be generated from fossil, nuclear and/or renewable sources. Around half of the electricity in the EU is generated from fossil fuels, and the remaining half from nuclear power stations and renewable sources (both $\approx 25 \%$ ) [7]. Wind turbines $(11.4 \%)$ and hydropower plants (10.4\%) account for most of the renewable energy sources [7]. Fossil fuels have been widely regarded as a prime cause of climate change because of the GHG emissions released by their burning [8]. Nuclear power plants pose serious potential risks to the environment and human health [9]. For most renewables, the main obstacles are their comparably lower energy output, intermittency and lower availability [10].

Carbon Emissions or $\mathrm{CO}_{2}$-Constrained Energy Planning is often labeled as Carbon Constrained Energy Planning (CCEP). It is a set of techniques that is suitable for power generation planning constrained by $\mathrm{CO}_{2}$ emissions [11]. Several techniques have been developed, such as insight-based approaches under the framework of Carbon Emission Pinch Analysis (CEPA) [12], algebraic targeting approaches to CCEP [13] and optimization-based targeting techniques for single- and multi- period scenarios [14]. Various extensions of the methodology have been proposed, such as an algebraic targeting approach (cascade analysis technique) for land-constrained energy planning [13], a graphical Pinch approach for water footprint-constrained energy planning, applied to biofuel production [15], improved application of CEPA to large transport systems [16], a graphical approach of CEPA applied to economic systems [17], source-sink superstructure optimization of energy planning under multiple footprint constraints [18], and various other CCEP methodology extensions. Hybrid CEPA techniques have also been developed, for instance with P-graph for macro-level [19] and plant-level planning [20] problems.

CCEP belongs to a broader category of Process Integration (PI) [21], which includes Heat Integration [22], Total Site (TS) Integration [23], Heat and Power Integration [24], Mass Integration and Resource Conservation [25], Hydrogen Pinch Analysis (PA) [26], Oxygen PA [27], Targeting Supply Chains performance [28], Targeting Property-Based Material Reuse [29], Targeting Carbon Footprint Reduction [30] and others. PI is a widely researched area, and many advancements have been made over the years. On the Science Direct platform, there are 8959 entries containing "Process Integration" in their title from 2019-2020 (search made on 8 May 2020). Also, various PI works have been published in the Energies journal. Among recent works are a review on progress towards efficient and clean PI [31], an analysis of PI options for different types of heat pumps through Pinch Technology [32], a proposed novel PA methodology to target cooling, heating and power in TSs [33], the incorporation of location aspects in PI methodology [34] and others, while only one work is related to carbon emissions planning [35].

Most studies applying CCEP techniques have focused on power generation, while only a few have focused on industries or specific industrial products. Tjan et al. [30] developed a graphical variant and applied it to the analysis of bulk and specialty chemicals; this method was later extended to consider allocation issues in multiproduct biorefineries [36]. Quin et al. [37] investigated product-based CCEP focused on energy-emission planning for the methanol production industry in China. Sinha and Chaturvedi [38] focused on CCEP for steel manufacturing, while Abdul Aziz et al. [39] presented a newly developed framework for low- $\mathrm{CO}_{2}$-emission industrial site planning. Recently, 
Sinha and Chaturvedi [40] reviewed carbon reduction technologies in industries with a focus on carbon emission limits planning.

Based on the literature review, it was found that none of the studies focused on CCEP applied to the aluminum industry and to specific aluminum products. It is also worth noting that most of the CCEP studies considered only one approach to energy planning for specific applications, while this study considers three different approaches: the first is the graphical approach of CEPA, the second is the algebraic approach implementing a cascade analysis technique, and the third is the optimization-based approach, applying a transportation model [13].

The aim of this study is the determination of the required amount of $\mathrm{CO}_{2}$ emissions from electricity sources to meet specified $\mathrm{CO}_{2}$ emission limits, considering the aforementioned approaches. All three approaches are systematic, which provides decision support in determining an appropriate energy mix to achieve a specific target, by considering the characteristics of energy sources and demands. CCEP techniques provide support in planning for more sustainable production of industrial products. They can also be used to optimize the energy supply mix based on carbon emission constraints subject to economic and other environmental constraints, except for carbon footprint and the like. This study focuses on the production of more sustainable aluminum products, and is the first CCEP work applied to the aluminum industry. CCEP approaches are applied to one aluminum product, i.e., aluminum slugs (graphical and numerical approaches), and two aluminum products, i.e., slugs and evaporator panels (all three approaches). All three approaches are finally compared and discussed.

\section{Carbon Emission-Constrained Electricity Planning for Aluminum Products}

Aluminum is widely available and is the second most widely used metal worldwide. Aluminum is used in several sectors, including transportation, packaging, building and construction, furniture, equipment and machinery. However, the aluminum industry is highly energy-consuming, especially in the production of primary aluminum. Aluminum production consumes about $3.5 \%$ of electricity globally [41], while in China [42] and the US [43], that figure is around 5\% and in Montenegro it is more than 25\% [44]. According to data from the Slovenian Ministry of Infrastructure [45] and the data collected by the authors, aluminum production in Slovenia consumed about $8.9 \%$ of the total electricity produced in 2017. Primary production of aluminum starts with bauxite mining and further refining of alumina from bauxite. Alumina is further processed into aluminum via electrolysis, known also as the Hall-Héroult process. Subsequently, aluminum is processed into a range of products by casting, rolling, extrusion and other operations [46]. The highest energy consumption and $\mathrm{CO}_{2}$ emissions are due to electrolysis [47]. The production of secondary or recycled aluminum, on the other hand, requires less than $5 \%$ of the energy required to produce aluminum from ore [48].

The aim of this study is to minimize $\mathrm{CO}_{2}$ emissions in order to meet specified $\mathrm{CO}_{2}$ emission limits, which could be set at the national or regional level. The emission limit (target) for this study was set at $0.376 \mathrm{t} \mathrm{CO}_{2} / \mathrm{MWh}$ [5]. This value was set by the European Commission in delegated regulation (EU) 2019/331, where transitional rules for the free allocation of emission allowances were set for the period 2021-2030. This emission factor is used for the determination of indirect emissions, where a given factor $\left(0.376 \mathrm{t} \mathrm{CO}_{2} / \mathrm{MWh}\right)$ is multiplied by the electricity consumption required to produce specific products.

In this study, two aluminum products are considered, aluminum slugs and evaporator panels. The production of aluminum slugs and evaporator panels is described in Figure 1. Both products are made from molten aluminum produced by the electrolysis process, while slugs are also made from recycled aluminum produced as process waste material from the further processing of slugs. This study performs CCEP of aluminum products for a Slovenian aluminum company. In the company, aluminum slugs are produced from around $0.67 \mathrm{t}$ of electrolysis aluminum per $\mathrm{t}$ of slugs; the remaining material used for their production is secondary aluminum. Aluminum evaporator panels are produced only from electrolysis aluminum, where from $1 \mathrm{t}$ of molten aluminum, about $1 \mathrm{t}$ of evaporator panels are produced. 


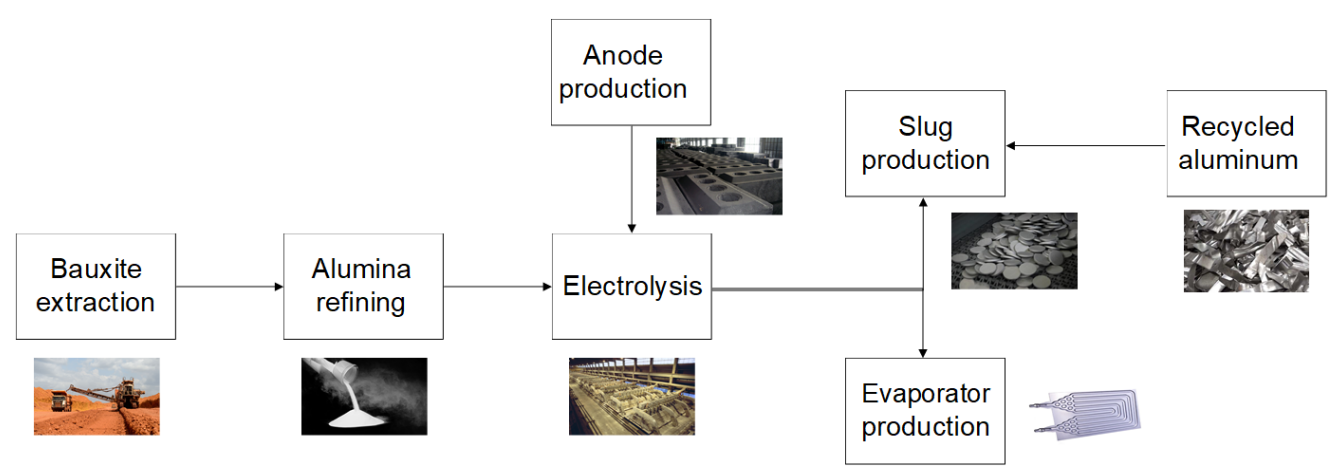

Figure 1. Production of aluminum slugs and evaporator panels (modified from [47]).

Aluminum slug production (see Figure 1) consists of casting, the production of the narrow strip, hot and cold rolling, stamping, annealing, surface treatment and packaging [47]. The production process of Roll-Bond evaporator panels also consists of several steps: casting of the wide strip, rolling it into the band for evaporator panels, roll-bonding, recrystallization annealing, inflation of imprinted channels, final dimension cut or stamping and packaging, and final assembly of the evaporator panels according to the needs of the customer. Both production processes follow the same value chain up to slug and evaporator panel production.

For the sake of simplification, the same amount of the primary aluminum used in the production of aluminum slugs and evaporator panels is assumed; $0.67 \mathrm{t}$ of primary aluminum is required for the production of $1 \mathrm{t}$ of aluminum slugs, and the same amount of primary aluminum is used for $0.67 \mathrm{t}$ of aluminum evaporator panels. To produce $0.67 \mathrm{t}$ of primary aluminum, $0.063 \mathrm{MWh}$ of electricity are required for the anode production and 9.12 MWh for the electrolysis. This consumption is the same for both products, since they follow the same value chain up to the final steps. They have similar electricity consumption, although the production of evaporator panels requires slightly more electricity. For slug production, an additional $0.263 \mathrm{MWh}$ of electricity is required for $1 \mathrm{t}$ of the product, while for evaporator panels, an additional $1.016 \mathrm{MWh}$ of electricity is required for $0.67 \mathrm{t}$ of the product. Total electricity consumption for $1 \mathrm{t}$ of slugs is $9.446 \mathrm{MWh}$, and for $0.67 \mathrm{t}$ of evaporator panels is 10.199 MWh.

The electricity delivered to a company is generated from a mix of fossil, nuclear and renewable energy sources. Electricity sources of fossil origin are coal, lignite, natural gas and oil. Hydro, wind, photovoltaics, geothermal, biomass, biogas and biodiesel are considered types of renewable energy. For the sake of simplification, energy sources are grouped into three main categories. Fractions of energy sources in the electricity mix, and emission factors of the different sources are summarized in Table 1. Average values for prices and emission factors are used for each energy source. The prices for each energy source are regarded as confidential and thus they are not presented.

Table 1. Data used in the study.

\begin{tabular}{ccccc}
\hline Energy Source & Fraction & $\begin{array}{c}\text { Emission Factor } \\
\left(\mathbf{t ~} \mathbf{C O}_{2} / \mathbf{M W h}\right)\end{array}$ & Product & $\begin{array}{c}\text { Consumption } \\
\text { (MWh/t) }\end{array}$ \\
\hline Nuclear & 0.2602 & 0.008 & Slug & 9.446 \\
Renewable & 0.1509 & 0.038 & Evaporator panels & 10.199 \\
Fossil & 0.5889 & 1.015 & & \\
\hline
\end{tabular}

Three different energy planning approaches (graphical, algebraic and optimization-based approaches) will be demonstrated in the following sections. The first two approaches are presented and illustrated on one aluminum product (aluminum slugs) and are shown for zero- and low-carbon energy sources (in the current work, the low-carbon energy source is renewable energy). The third approach deals with two aluminum products (aluminum slugs and evaporator panels) and considers 
two cases: the case where electricity is pinched for each product, and the hypothetical case where only one Pinch exists for both products. In the case of optimization, the trade-off solution is obtained between emissions and the cost of energy sources to achieve a given benchmark.

Graphical and numerical approaches consist of several steps and follow similar algorithms whose detailed steps are described in related previous papers. First, energy supply and demand are defined; then, they are arranged into emission intervals (segments) by increasing the emission factors from the lowest to the highest. By the graphical approach, the energy source and demand curves are then plotted on the energy consumption-emissions diagram. The energy source curve is further shifted horizontally until it intersects with the energy demand curve (at the "Pinch Point") [12]. By the numerical approach, the energy surplus/deficit is cascaded through the intervals, and the cumulative net energy consumption should be non-negative. The deficit should then be added to the zero- or low-carbon energy source [13]. The optimization approach, on the other hand, involves formulating a working model whose solution is determined numerically via established solution techniques (i.e., Simplex algorithm) that is embedded in standard optimization software. The data and variables should be defined, and together with the constraints, they form a feasible region. The optimal solution is then defined based on the given objective, which is minimized or maximized. The procedure for each approach is described in more detail, together with the case studies, in the following section.

\section{Graphical Targeting Approach}

The first technique for CCEP is the insight-based graphical targeting approach, called CEPA, originally developed in 2007 by Tan and Foo [12]. CEPA uses a graphical approach based on the principles of conventional PA [21]; it enables the identification of the minimum amount of low- or zero-carbon energy needed to satisfy demand-side emission constraints (target) [49]. Note that the term "zero-carbon" is usually applied to sources with very low $\mathrm{CO}_{2}$ intensity compared to fossil fuels, even if the actual magnitude is nonzero. Various applications and extensions of the CEPA methodology have been developed recently, such as applications to energy sectors in different countries (Ireland [50], New Zealand [51], USA [52], China [53], Nigeria [54], the Baltic States [55], the EU [56] and others), alternative metrics and footprints (land [13], water [15]), and other sectors, such as transport systems [16], economic systems [17] and others. Conceptual or graphical techniques applied in PA are useful tools in the preliminary stages of energy planning, energy policy [57], in graphical representation, in step-by-step user control and in the verification of results. The graphical display also provides visualization that is useful for the analysis of a problem and subsequent communication of the results. On the other hand, graphical methods are limited to relatively simple problems [12]. Another limitation could be the accuracy of the results, which depends on the quality of the graphical display [12].

All the steps of the CEPA algorithm are presented in detail by Tan and Foo [12]. The first step in the CEPA procedure is the preparation of the energy source and demand data, which are shown in Table 2. Energy sources are sorted in order of increasing emission factors (see also Table 1). The consumption described in Table 2 (in $\mathrm{MWh} / \mathrm{t}$ ) was obtained by multiplying the fraction of the energy source by the total consumption of electricity for the production of aluminum slugs $(9.446 \mathrm{MWh} / \mathrm{t})$. As stated previously, only one product (aluminum slugs) was considered for the graphical and algebraic approaches. Emissions (in $\mathrm{tCO}_{2} / \mathrm{t}$ ) were obtained by multiplying the emission factor and total electricity consumption for $1 \mathrm{t}$ of slugs. Energy demand represents the total consumption of electricity for $1 \mathrm{t}$ of slugs with target emission constraints (benchmark of $\left.0.376 \mathrm{t} \mathrm{CO}_{2} / \mathrm{MWh}[5]\right)$. Emissions (3.552 $\mathrm{t} \mathrm{CO}_{2} / \mathrm{t}$ ) were obtained by multiplying the benchmark emission factor and total electricity consumption.

The second step in the CEPA procedure is the generation of source and demand composite curves (CCs). Source curves for energy supply were obtained as $\mathrm{CO}_{2}$ emissions vs. electricity supply plots, and demand curves as $\mathrm{CO}_{2}$ emissions vs. electricity demand plots. The horizontal axis represents electricity supply or demand, while $\mathrm{CO}_{2}$ emissions are plotted as the vertical axis. The slope of each electricity source is equal to its emission factor, while the slope of electricity demand is equal to 
benchmark emission factor. Fossil energy has the highest emission factor $\left(1.015 \mathrm{t} \mathrm{CO}_{2} / \mathrm{MWh}\right.$; see also Table 1) of all electricity sources and a much steeper slope compared to renewable and nuclear energy.

Table 2. Data required for CEPA.

\begin{tabular}{cccccc}
\hline Source & $\begin{array}{c}\text { Consumption } \\
(\mathbf{M W h} / \mathbf{t})\end{array}$ & $\begin{array}{c}\text { Emissions } \\
\left(\mathbf{t ~ C O}_{\mathbf{2}} / \mathbf{t}\right)\end{array}$ & Demand & $\begin{array}{c}\text { Consumption } \\
(\mathbf{M W h} / \mathbf{t})\end{array}$ & $\begin{array}{c}\text { Emissions } \\
\left(\mathbf{t ~ C O}_{\mathbf{2}} / \mathbf{t}\right)\end{array}$ \\
\hline Nuclear & 2.458 & 0.020 & Slugs & 9.446 & 3.552 \\
Renewable & 1.425 & 0.054 & & & \\
Fossil & 5.563 & 5.646 & & & \\
SUM & 9.446 & 5.720 & & & \\
\hline
\end{tabular}

The next step is to construct source and demand CCs (see Figures 2 and 3). The source curve consists of three segments, i.e., nuclear, renewable, and fossil segments, and is constructed by arranging the segments end-to-end in ascending order of emission factors. The resulting source CC curls upwards [12]. The demand curve consists of only one segment, i.e., target $\mathrm{CO}_{2}$ emissions for $1 \mathrm{t}$ of aluminum slugs. The demand curve is thus linear over the entire interval.

To supply suitable energy sources that meet the $\mathrm{CO}_{2}$ emissions targets, the source $\mathrm{CC}$ is then shifted to the right. The Pinch Point is where the demand curve touches the shifted source curve. On the lower end of the shifted source CC (minimum distance between origin and shifted CC) is the minimum amount of zero-carbon energy sources needed to meet the $\mathrm{CO}_{2}$ emission limit, while at the upper end (distance between the Pinch Point and the end of the shifted source CC) is excess energy from fossil sources. At the lower end, it is generally desirable to maximize the use of zeroor low-carbon sources [58], while at the upper end, it is desirable to minimize the use of the most carbon-intensive energy source. Figure 2 shows a Pinch diagram for $1 \mathrm{t}$ of aluminum slug production while minimizing the zero-carbon energy source.

The minimum amount of zero-carbon energy (Figure 2) in this study is the same as the excess of the fossil source because of the same amount of electricity supply and demand. The graphical approach shows that for $1 \mathrm{t}$ of aluminum slugs, about 2.14 MWh of the fossil source should be replaced with zero-carbon energy to achieve an emission limit of $3.552 \mathrm{t} \mathrm{CO}_{2}$. As is shown in the left-upper window of Figure 2, the zero-carbon source has a zero slope, and nuclear energy, which is the lowest carbon emission source, is shifted for the minimum zero-carbon energy source to the right.

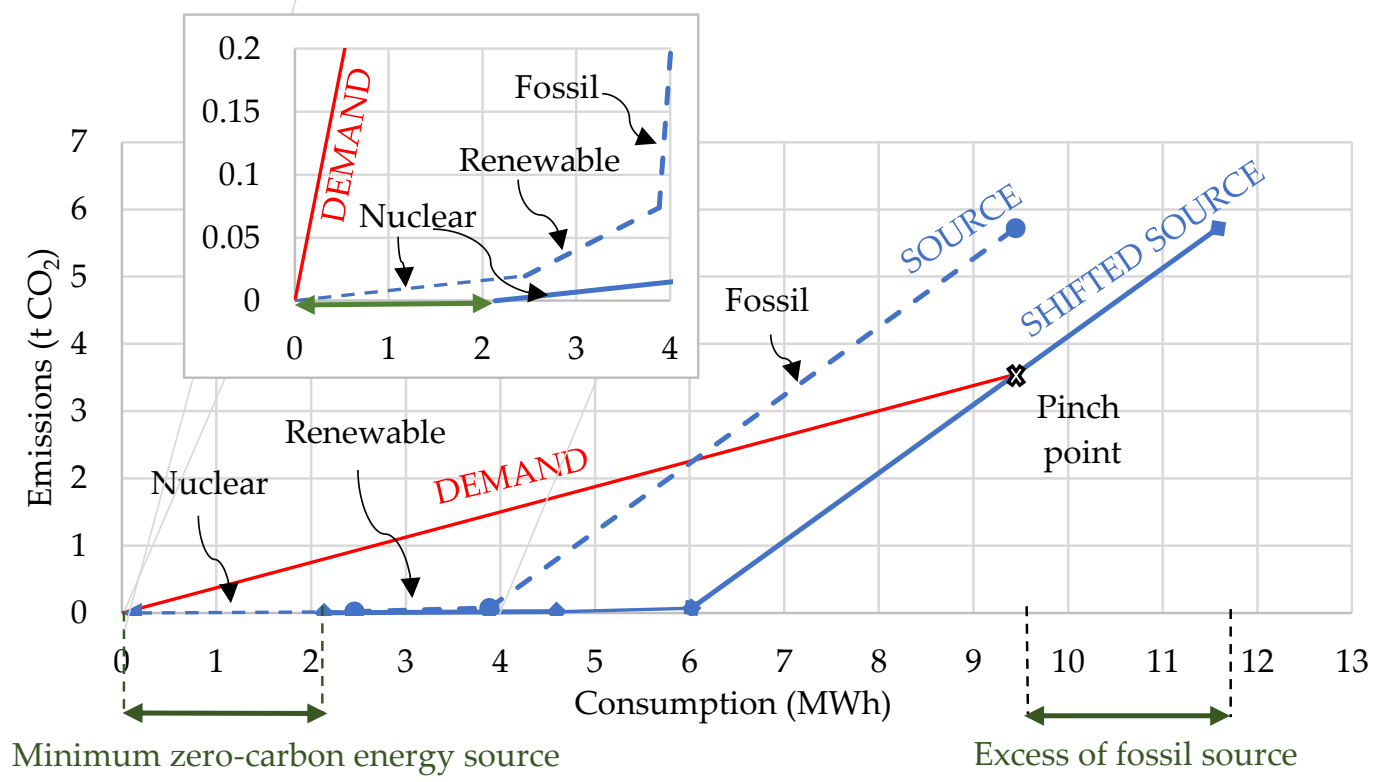

Figure 2. Pinch diagram for $1 \mathrm{t}$ of aluminum slugs with a minimum zero-carbon source. 


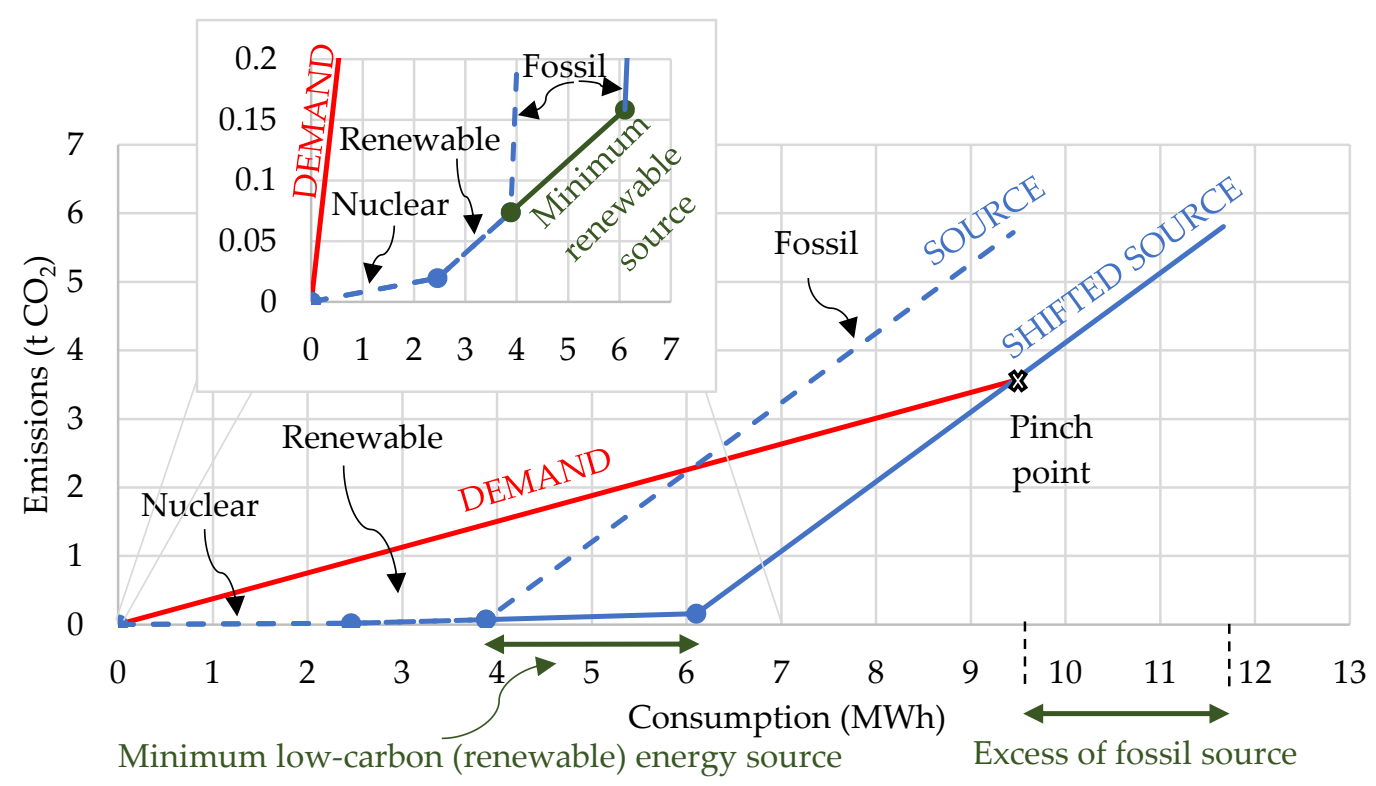

Figure 3. Pinch diagram for $1 \mathrm{t}$ of aluminum slugs with a minimum low-carbon (renewable) source.

However, it should be noted that it is virtually impossible to produce electricity with no $\mathrm{CO}_{2}$ emissions (zero-carbon electricity). Even renewable energy sources can only approach $\mathrm{CO}_{2}$ neutrality, but they do not reach it [58]. In many cases, it is more desirable to minimize the low-carbon energy source. Renewable energy is assumed to be a low-carbon energy source in this study, as it exhibits a low emission factor, with advantages such as renewability. Figure 3 shows a Pinch diagram for $1 \mathrm{t}$ of aluminum slugs with a minimum low-carbon energy source (renewable energy). In the low-carbon case, about 2.22 MWh is the minimum low-carbon energy source, and the same amount of energy is the excess of the fossil source. Owing to the addition of the low-carbon source, slightly more excess energy from the fossil source with the highest emission factor is obtained compared to the zero-carbon example.

Both cases (zero- and low-carbon energy source) will also be presented using the algebraic targeting approach.

\section{Algebraic Targeting Approach (Cascade Analysis)}

The algebraic targeting approach with the cascade analysis technique was originally developed for resource conservation networks [59], and has its roots in the Problem Table Algorithm and the Heat Cascade developed for Maximum Heat Recovery networks [21]. Cascade analysis for CCEP is an algebraic targeting approach for the identification and determination of the minimum amount of zeroand/or low-carbon sources to achieve emission limits. The method was introduced by Foo et al. [13] and could overcome the inaccuracy problems of the graphical approach.

Cascade analysis for determining the minimum amount of zero- or low-carbon sources consists of various steps [13], all of which are presented in detail by Foo et al. [13]. In the following section, the steps of the algorithm are demonstrated on an example which targets electricity demand in the production of $1 \mathrm{t}$ of aluminum slugs.

In the first column of the cascade analysis table (see Tables 3-6), emission factors are sorted in ascending order in $k$ intervals $\left(c_{k}\right)$. Their increments between successive rows $\left(\Delta c_{k}\right)$ are presented in the second column of the cascade analysis table. The following columns represent energy demand $\left(D_{j}\right)$ and energy source $\left(S_{i}\right)$ at the interval of the corresponding emission factor, where the number of intervals $k$ is equal to the number of energy demand $(j)$ and source types $(i)$. The difference between supply and demand $\left(S_{i}-D_{j}\right)$ gives the net surplus or deficit of energy at each interval $k$. A cumulative energy surplus or deficit $\left(F_{k}=\Delta\left(S_{i}-D_{j}\right)\right)$ is the sum of increments between successive rows, starting from 
either a zero-carbon or a low-carbon source. In the next column, the $\mathrm{CO}_{2}$ emission load at interval $k$ $\left(E_{k}\right)$ is calculated as:

$$
E_{k}=F_{k} \cdot \Delta c_{k}
$$

Next, the cumulative $\mathrm{CO}_{2}$ load $\left(\Delta E_{k}\right)$ between successive rows of $E_{k}$ is calculated. If $\Delta E_{k}$ has a negative value, the $\mathrm{CO}_{2}$ limit has been exceeded, and the cascade is infeasible. In the last column, clean source demand at interval $k\left(F_{C S, k}\right)$ is shown, which is calculated as:

$$
F_{C S, k}=\frac{\Delta E_{k}}{c_{k}-c_{C S}}
$$

where $c_{C S}$ represents an emission factor or the clean (zero- or low-carbon) energy source.

In the following section, both cases will be shown, i.e., the minimum demand for the zero- and low-carbon energy sources. The cascade analysis approach was implemented in Excel by using the actual (not rounded) numbers for calculations.

\subsection{Minimum Demand for the Zero-Carbon Source}

First, the demand for the zero-carbon source was determined to achieve the specified emission limits. The data used in the study are as shown in Table 1. Cascade analysis was applied to one aluminum product, i.e., aluminum slugs, and is shown in Table 3.

The analysis in Table 3 shows an infeasible cascade for a minimum zero-carbon energy source. A feasible cascade should have a non-negative value for the cumulative $\mathrm{CO}_{2}$ load in the last interval. A feasible cascade is shown in Table 4, where almost all the steps remain the same as before. The exception is that the largest negative value of $F_{C S, k}$ is considered as the quantity of the zero-carbon energy source, and is taken as an absolute positive value.

\begin{tabular}{|c|c|c|c|c|c|c|c|c|}
\hline $\begin{array}{c}c_{k} \\
\left(\mathrm{t} \mathrm{CO}_{2} / \mathrm{MWh}\right)\end{array}$ & $\begin{array}{c}\Delta c_{k} \\
\text { (t CO } / \mathrm{MWh})\end{array}$ & $\begin{array}{c}D_{j} \\
\text { (MWh) }\end{array}$ & $\begin{array}{c}S_{i} \\
\text { (MWh) }\end{array}$ & $\begin{array}{l}S_{i}-D_{j} \\
\text { (MWh) }\end{array}$ & $\begin{array}{c}F_{k} \\
\text { (MWh) }\end{array}$ & $\begin{array}{c}E_{k} \\
\left(\mathrm{t} \mathrm{CO}_{2}\right)\end{array}$ & $\begin{array}{c}\Delta E_{k} \\
\left(\mathrm{t} \mathrm{CO}_{2}\right)\end{array}$ & $\begin{array}{l}F_{C S, k} \\
\text { (MWh) }\end{array}$ \\
\hline \multicolumn{9}{|l|}{0} \\
\hline \multirow{3}{*}{0.008} & 0.008 & & & & 0 & 0 & & \\
\hline & & & 2.458 & 2.458 & & & 0 & 0 \\
\hline & 0.030 & & & & 2.458 & 0.074 & & \\
\hline \multirow[t]{2}{*}{0.038} & & & 1.425 & 1.425 & & & 0.074 & 1.941 \\
\hline & 0.338 & & & & 3.883 & 1.312 & & \\
\hline \multirow[t]{2}{*}{0.376} & & 9.446 & & -9.446 & & & 1.386 & 3.687 \\
\hline & 0.639 & & & & -5.563 & -3.555 & & \\
\hline \multirow[t]{2}{*}{1.015} & & & 5.563 & 5.563 & & & -2.169 & -2.137 \\
\hline & & & & & 0 & & & \\
\hline
\end{tabular}

Table 3. Cascade analysis for zero-carbon energy source where not all $\mathrm{CO}_{2}$ loads are non-negative.

\begin{tabular}{|c|c|c|c|c|c|c|c|c|}
\hline $\begin{array}{c}c_{k} \\
\left(\mathrm{t} \mathrm{CO}_{2} / \mathrm{MWh}\right)\end{array}$ & $\begin{array}{c}\Delta c_{k} \\
(\mathrm{t} \mathrm{CO} / \mathrm{MWh})\end{array}$ & $\begin{array}{c}D_{j} \\
\text { (MWh) }\end{array}$ & $\begin{array}{c}S_{i} \\
(\mathrm{MWh})\end{array}$ & $\begin{array}{l}S_{i}-D_{j} \\
\text { (MWh) }\end{array}$ & $\begin{array}{c}F_{k} \\
(\mathrm{MWh})\end{array}$ & $\begin{array}{c}E_{k} \\
\left(\mathrm{t} \mathrm{CO}_{2}\right)\end{array}$ & $\begin{array}{c}\Delta E_{k} \\
\left(\mathrm{t} \mathrm{CO}_{2}\right)\end{array}$ & $\begin{array}{c}F_{C S, k} \\
(\mathbf{M W h})\end{array}$ \\
\hline \multirow[t]{2}{*}{0} & & & 2.137 & 2.137 & & & & \\
\hline & 0.008 & & & & 2.137 & 0.017 & & \\
\hline \multirow[t]{2}{*}{0.008} & & & 2.458 & 2.458 & & & 0.017 & 2.137 \\
\hline & 0.030 & & & & 4.595 & 0.138 & & \\
\hline \multirow[t]{2}{*}{0.038} & & & 1.425 & 1.425 & & & 0.155 & 4.077 \\
\hline & 0.338 & & & & 6.020 & 2.035 & & \\
\hline \multirow[t]{2}{*}{0.376} & & 9.446 & & -9.446 & & & 2.190 & 5.823 \\
\hline & 0.639 & & & & -3.426 & -2.190 & & \\
\hline \multirow[t]{2}{*}{1.015} & & & 5.563 & 5.563 & & & $0 *$ & 0 \\
\hline & & & & & 2.137 & & & \\
\hline
\end{tabular}

Table 4. Minimum zero-carbon energy solution applying cascade analysis. 
The negative value of $F_{C S, k}$ in the last interval from Table $3(-2.137 \mathrm{MWh})$ is the amount of required zero-carbon energy source $S_{i}$ in the first interval in Table 4 (where emission factor $c_{k}$ is zero). In this way, the cascade is adjusted to become feasible. From Table 4, it can also be seen that the excess energy from the fossil source is the same as the minimum amount of zero-carbon energy (2.137 MWh; last interval of $F_{k}$ ). The Pinch Point is obtained at interval $k$, where $\Delta E_{k}$ is equal to zero, which is at $1.015 \mathrm{tCO}_{2} / \mathrm{MWh}$.

\subsection{Minimum Demand for the Low-Carbon Source}

The algebraic targeting approach is further extended to determine the amount of the low-carbon energy source to achieve the specified emission limits. All steps in the cascade analysis remain the same as for the zero-carbon example, except that $S_{i}$ for the renewable energy source is now the sum of the previous amount of renewable energy source $(1.425 \mathrm{MWh})$ plus the minimum amount of zero-carbon energy obtained above (2.137 MWh, see Table 4). $F_{C S, k}$ was obtained by considering a $c_{C S}$ of 0.038 (see also Table 1). The cascade analysis determining the minimum amount of the low-carbon energy source is shown in Table 5.

Table 5. Cascade analysis for the low-carbon energy source where not all $\mathrm{CO}_{2}$ loads are non-negative.

\begin{tabular}{|c|c|c|c|c|c|c|c|c|}
\hline $\begin{array}{c}c_{k} \\
\text { (t CO} 2 / \mathrm{MWh})\end{array}$ & $\begin{array}{c}\Delta c_{k} \\
\left(\mathrm{t} \mathrm{CO}_{2} / \mathrm{MWh}\right)\end{array}$ & $\begin{array}{c}D_{j} \\
\text { (MWh) }\end{array}$ & $\begin{array}{c}S_{i} \\
\text { (MWh) }\end{array}$ & $\begin{array}{l}S_{i}-D_{j} \\
\text { (MWh) }\end{array}$ & $\begin{array}{c}F_{k} \\
\text { (MWh) }\end{array}$ & $\begin{array}{c}E_{k} \\
\left(\mathrm{t} \mathrm{CO}_{2}\right)\end{array}$ & $\begin{array}{c}\Delta E_{k} \\
\left(\mathrm{t} \mathrm{CO}_{2}\right)\end{array}$ & $\begin{array}{c}F_{C S, k} \\
(\mathrm{MWh})\end{array}$ \\
\hline \multicolumn{9}{|l|}{0} \\
\hline \multirow{3}{*}{0.008} & 0.008 & & & & 0 & 0 & & \\
\hline & & & 2.458 & 2.458 & & & 0 & 0 \\
\hline & 0.030 & & & & 2.458 & 0.074 & & \\
\hline \multirow[t]{2}{*}{0.038} & & & 3.562 & 3.562 & & & 0.074 & Undef * \\
\hline & 0.338 & & & & 6.020 & 2.035 & & \\
\hline \multirow[t]{2}{*}{0.376} & & 9.446 & & -9.446 & & & 2.109 & 6.238 \\
\hline & 0.639 & & & & -3.426 & -2.189 & & \\
\hline \multirow[t]{2}{*}{1.015} & & & 5.563 & 5.563 & & & -0.081 & -0.083 \\
\hline & & & & & 2.137 & & & \\
\hline
\end{tabular}

* undef-result is undefined because of division by zero.

Table 6. Minimum low-carbon energy solution applying cascade analysis.

\begin{tabular}{|c|c|c|c|c|c|c|c|c|}
\hline $\begin{array}{c}c_{k} \\
(\mathrm{t} \mathrm{CO} / \mathrm{MWh})\end{array}$ & $\begin{array}{c}\Delta c_{k} \\
\text { (t CO } / \mathrm{MWh})\end{array}$ & $\begin{array}{c}D_{j} \\
\text { (MWh) }\end{array}$ & $\begin{array}{c}S_{i} \\
\text { (MWh) }\end{array}$ & $\begin{array}{l}S_{i}-D_{j} \\
\text { (MWh) }\end{array}$ & $\begin{array}{c}F_{k} \\
\text { (MWh) }\end{array}$ & $\begin{array}{c}E_{k} \\
\left(\mathrm{t} \mathrm{CO}_{2}\right)\end{array}$ & $\begin{array}{c}\Delta E_{k} \\
\left(\mathrm{t} \mathrm{CO}_{2}\right)\end{array}$ & $\begin{array}{l}F_{C S, k} \\
\text { (MWh) }\end{array}$ \\
\hline \multicolumn{9}{|l|}{0} \\
\hline \multirow{3}{*}{0.008} & 0.008 & & & & 0 & 0 & & \\
\hline & & & 2.458 & 2.458 & & & 0 & 0 \\
\hline & 0.030 & & & & 2.458 & 0.074 & & \\
\hline \multirow[t]{2}{*}{0.038} & & & 3.645 & 3.645 & & & 0.074 & undef \\
\hline & 0.338 & & & & 6.103 & 2.063 & & \\
\hline \multirow[t]{2}{*}{0.376} & & 9.446 & & -9.446 & & & 2.136 & 6.321 \\
\hline & 0.639 & & & & -3.343 & -2.136 & & \\
\hline \multirow[t]{2}{*}{1.015} & & & 5.563 & 5.563 & & & 0 * & 0 \\
\hline & & & & & 2.220 & & & \\
\hline
\end{tabular}

* Pinch Point.

The cascade analysis in Table 5 gives an infeasible solution for the low-carbon source owing to the negative value of $\Delta E_{k}$ in the last interval. A feasible solution to the cascade analysis is shown in Table 6, where again, the most negative value of $F_{C S, k}(-0.083 \mathrm{MWh})$ is added to the low-energy source $\left(S_{i}\right.$ for renewable energy source with $c_{k}$ of 0.038). This is the amount (in absolute numbers) of the required addition to the low-carbon supply shown in Table 5 (3.562 MWh, increased to 3.645).

As obtained also by the graphical approach, the amount of excess energy from fossil sources is increased to 2.22 MWh. The Pinch Point is again obtained at $1.015 \mathrm{t} \mathrm{CO}_{2} / \mathrm{MWh}$.

In the following section, the optimization-based approach is used to minimize the cost of electricity sources while achieving $\mathrm{CO}_{2}$ emission targets. Two products are considered for optimization, i.e., aluminum slugs and aluminum evaporator panels. 


\section{Optimization-Based Approach}

Mathematical Programming (MP) is another broad category of PI methodologies [60]. MP enables the search to be automated, while finding the optimal solution among many design alternatives [61]. The simplest representation of the MP model is defined as a deterministic model (the model where all the parameters are constant and not uncertain or random), and is written in the form of a Linear Program (LP). One advantage over the previous two approaches is the flexibility to change the objective function to suit the context of the problem. For PI problems, one of the first problem formulations of MP was the transportation model [62].

The transportation model (its variants are also known as the source-sink model or resource-allocation problem) is based on the principle that a product is transported from a number of sources to a number of sinks (destinations) based on a given objective (minimum cost, maximum profit, etc.). Dealing with both mass and energy for CCEP problems as extensive properties, in contrast to temperature in Heat Integration, which is an intensive property, the transportation model is a suitable approach for solving CCEP problems. The transportation model, which is written in a generic way and could be applied to any transportation or planning problem, is shown in Equations (3)-(7). The sets, data and variables applied in the transportation model are described on the left.

$$
\begin{gathered}
\sum_{j} x_{i j} \leq a_{i}, \forall i \in I \\
\sum_{i} x_{i j}=b_{j}, \forall j \in J \\
\sum_{i} x_{i j} F_{i}=E_{j}, \forall j \in J \\
w_{i j}=\frac{x_{i j}}{b_{j}}, \forall i \in I, j \in J \\
\min z=\sum_{i j} x_{i j} P_{i}
\end{gathered}
$$

\section{Sets}

$I$ source (fossil, nuclear, renewable) with elements $i \in I$

$J$ demand (slug, evaporator panels) with elements $j \in J$

\section{Parameters}

$a_{i} \quad$ supply or availability of energy source $i(\mathrm{MWh} / \mathrm{y})$

$b_{j}$ demand for electricity to produce product $j(\mathrm{MWh})$

$F_{i}$ emission factor for electricity source $i\left(\mathrm{t} \mathrm{CO}_{2} / \mathrm{MWh}\right)$

$P_{i}$ price of electricity source $i$ (EUR/MWh)

\section{Positive variable}

$x_{i j}$ amount of electricity from source $i$ to demand $j(\mathrm{MWh} / \mathrm{y})$

$w_{i j}$ fraction of electricity source $i$ to produce product $j(-)$

$E_{j} \quad \mathrm{CO}_{2}$ emissions for each product $j\left(\mathrm{t} \mathrm{CO}_{2} / \mathrm{t}\right.$ products $)$

Equation (3) is calculated for each source $i$, and implies that the sum of specific electricity source $i$ consumed for all $j$ products $\left(x_{i j}\right)$ should be greater than or equal to the availability of that electricity source $i\left(a_{i}\right)$. Equation (4) is calculated for each demand for energy $j$ and requires that the amount of electricity from all the sources satisfy the demand for electricity to produce each product $j\left(b_{j}\right)$. $\mathrm{CO}_{2}$ emissions originating from electricity consumption for the production of each product $j\left(E_{j}\right)$ are 
calculated with Equation (5), where the amounts of electricity consumed $x_{i j}$ are multiplied by the emission factors for energy source $i\left(F_{i}\right)$. Equation (6) calculates the fraction of electricity source $i\left(w_{i j}\right)$ used to produce each product $j$. Finally, Equation (7) represents the objective, which is to minimize the cost of the electricity supply mix, which is calculated by multiplying the amount of electricity consumed $\left(x_{i j}\right)$ by the price of each electricity source $i\left(P_{i}\right)$.

Three different cases are studied:

- Current case: The electricity mix for producing aluminum slugs and evaporator panels is fixed to the current shares of each energy source in the mix. To simulate the current case, $\mathrm{CO}_{2}$ emissions are also fixed to their current emission values. To calculate the cost for the supply of electricity mix, Equations (3)-(7) are applied.

- Case 1: It is assumed that the electricity mix delivered to the company allows optimal fractions of the main energy sources to be in the electricity supply mix. Also, emission levels for each aluminum product should be achieved for every product. The upper emission limit is set to $3.55 \mathrm{t} \mathrm{CO}_{2} / \mathrm{t}$ slugs and to $3.835 \mathrm{t} \mathrm{CO}_{2}$ per $0.67 \mathrm{t}$ of evaporator panels. As explained previously, the emission limit is set to $0.376 \mathrm{t} \mathrm{CO}_{2} / \mathrm{MWh}$ of electricity, while $9.446 \mathrm{MWh}$ are required for $1 \mathrm{t}$ of slugs and $10.199 \mathrm{MWh}$ for $0.67 \mathrm{t}$ of evaporator panels. To calculate the cost for this case, Equations (3)-(7) are applied. where Equation (5) is reformulated so that emissions from electricity consumed do not exceed the upper emission limits for each product $j\left(3.55 \mathrm{t}\right.$ and $3.835 \mathrm{t} \mathrm{CO}_{2}$ ):

$$
\sum_{i} x_{i j} F_{i} \leq E_{j}, \forall j \in J
$$

- Case 2: This case is similar to Case 1, but here, it is assumed that the total emission level should be achieved for both aluminum products together. The upper emission limits are the same as those for the first case. Equation (5) is again reformulated to consider the upper limit on emissions for both products combined:

$$
\sum_{i, j} x_{i j} F_{i} \leq \sum_{j} E_{j}
$$

The models for the three cases determine the minimum cost of the electricity supply mix considering emission limits. The main results of the transportation model for the three cases are summarized in Table 7, where the fractions of the electricity sources used to produce each product and the total cost of electricity supply are shown. It should be noted that, for reasons of confidentiality, the values of cost are normalized, where a value of 1 represents the cost for current electricity mix.

Table 7 shows that the cost of the current electricity supply mix is lower by $26 \%$ compared to cases considering emission limits (Case 1 and 2). Currently, there is a relatively high share of fossil sources in the electricity mix, which is cheaper compared to nuclear and renewable sources. With the current electricity mix, however, emission levels cannot be achieved because of the higher emission factor of fossil energy (see also Table 1). For both the current case and Case 1, the fractions of electricity sources in the mix are the same for both products. Case 2 is a hypothetical case, where the fractions of sources in the electricity mix for slugs and evaporator panels are different. Renewable energy is not selected in either Case 1 and 2, owing to the higher emission factor and lower cost compared to nuclear energy.

The Pinch diagrams in the next sections show where an electricity consumption Pinch occurs for each product (Case 1), and when only one Pinch for all the products combined should be achieved (Case 2). 
Table 7. Main results from optimization.

\begin{tabular}{cccccccc}
\hline \multirow{2}{*}{ Product/Scenario Slugs } & \multicolumn{4}{c}{ Evaporator Panels } & \multirow{2}{*}{ Cost } \\
\cline { 2 - 7 } & $\boldsymbol{w}_{\text {fossil }}$ & $\boldsymbol{w}_{\text {nuclear }}$ & $\boldsymbol{w}_{\text {renewable }}$ & $\boldsymbol{w}_{\text {fossil }}$ & $\boldsymbol{w}_{\text {nuclear }}$ & $\boldsymbol{w}_{\text {renewable }}$ & \\
\hline Current & 0.590 & 0.260 & 0.150 & 0.590 & 0.260 & 0.150 & 1 \\
Case 1 & 0.365 & 0.635 & 0 & 0.365 & 0.635 & 0 & 1.26 \\
Case 2 & 0 & 1 & 0 & 0.704 & 0.296 & 0 & 1.26 \\
\hline
\end{tabular}

\subsection{Electricity Consumption Pinch for Each Product}

Case 1 presents the case whereby for each product, the emission limit should not be exceeded. Electricity consumption is pinched for each product, as shown in Figure 4. The source CC represents the current case, where emissions and the composition of the electricity mix for both products are fixed. The demand curve consists of two segments, one for each product. However, both segments have the same slope, since the $\mathrm{CO}_{2}$ emission benchmark is the same for both products $\left(0.376+\mathrm{CO}_{2} / \mathrm{MWh}\right.$ [5], as stated previously). For Case 1, it can be seen that both products use nuclear and fossil energy to reach the target, as presented in Table 7 . Renewable energy is not selected, as it has a higher emission factor and is more expensive than nuclear.

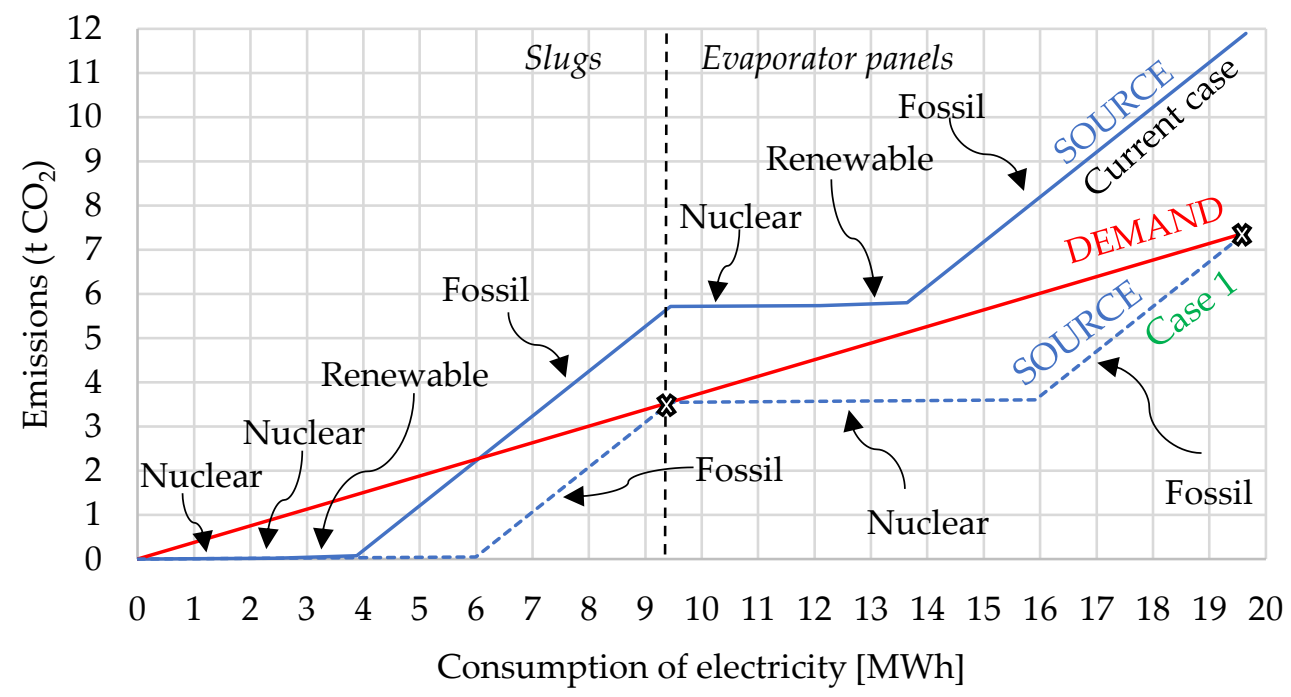

Figure 4. Pinch diagram for Case 1 when electricity consumption is pinched for each product.

A sensitivity analysis was further performed by fixing the fraction of renewable energy in the electricity supply mix. It is expected that the share from renewable sources will rise in future, while the expansion of nuclear in the future is less certain. The fraction of renewable energy is increased from $0 \%$ to $100 \%$. The results of the sensitivity analysis are shown in Figure 5 for fractions of fossil and nuclear sources (left) and cost (right).

It can be seen that the fraction of nuclear energy in the electricity mix decreases almost linearly with the increase in the renewable energy share in the electricity mix up to $w_{\text {renewable }}$ reaching about 0.7 . Subsequently, nuclear energy is no longer selected because of cheaper fossil electricity, while the emission limit is satisfied. Fossil source, on the other hand, remains almost constant, between $w_{\text {renewable }}$ 0 and about 0.7 . At higher values of $w_{\text {renewable, the fraction of } w_{\text {fossil }} \text { starts decreasing almost linearly }}$ with the increase in $w_{\text {renewable. }}$. It should be noted that $w_{\text {renewable }}+w_{\text {fossil }}+w_{\text {nuclear }}$ should always be equal to 1.

The cost of the electricity supply mix is shown in Figure 5 on the right. For reasons of confidentiality, the values of cost, on the vertical axis, are hidden. The lowest cost was obtained with no renewable energy in the supply mix (as shown in Table 7). It should be noted that renewable energy is the most expensive of all the sources (see Table 1), and the cost of electricity is constantly increasing with 


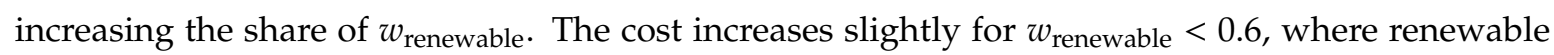
energy replaces nuclear. It begins to increase more significantly for $w_{\text {renewable }}>0.6$, when renewable replaces fossil energy, owing to the significant differences in price.
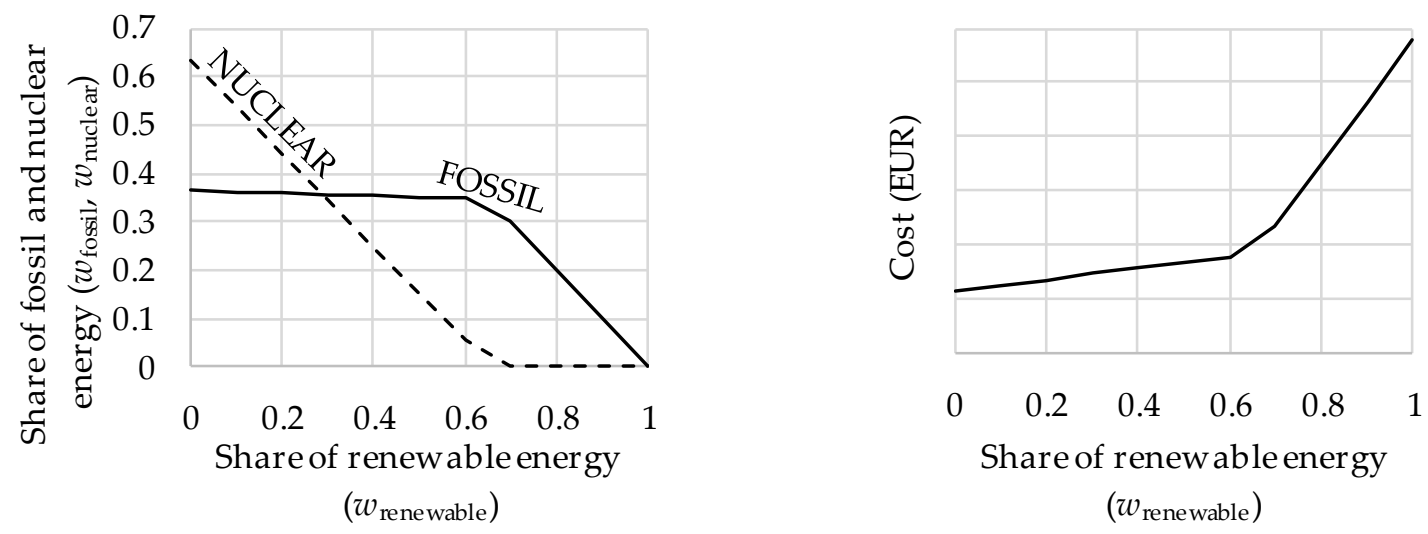

Figure 5. Composition of energy mix (left) and cost (right) while increasing the fraction of renewable energy in the electricity mix.

\subsection{Electricity Consumption Pinch for All the Products Considered}

Case 2 presents a hypothetical case where for all products, the overall emission limit should not be exceeded. Only one electricity Pinch is obtained for the total electricity demand, as shown in Figure 6. The demand curve is the same as in Case 1, while the source curves for the Current case and Case 2 are now different. Both source curves are arranged in ascending order of emission factors for all the products combined. It can be seen that for slugs, only nuclear energy is used, while for evaporator panels, first nuclear energy is used, and later, also fossil energy to satisfy benchmark $\mathrm{CO}_{2}$ emissions. It should be noted that even here, fossil energy is the preferred source because it has the lowest cost; thus Cases 1 and 2 both exhibit the same cost, as shown in Table 7 .

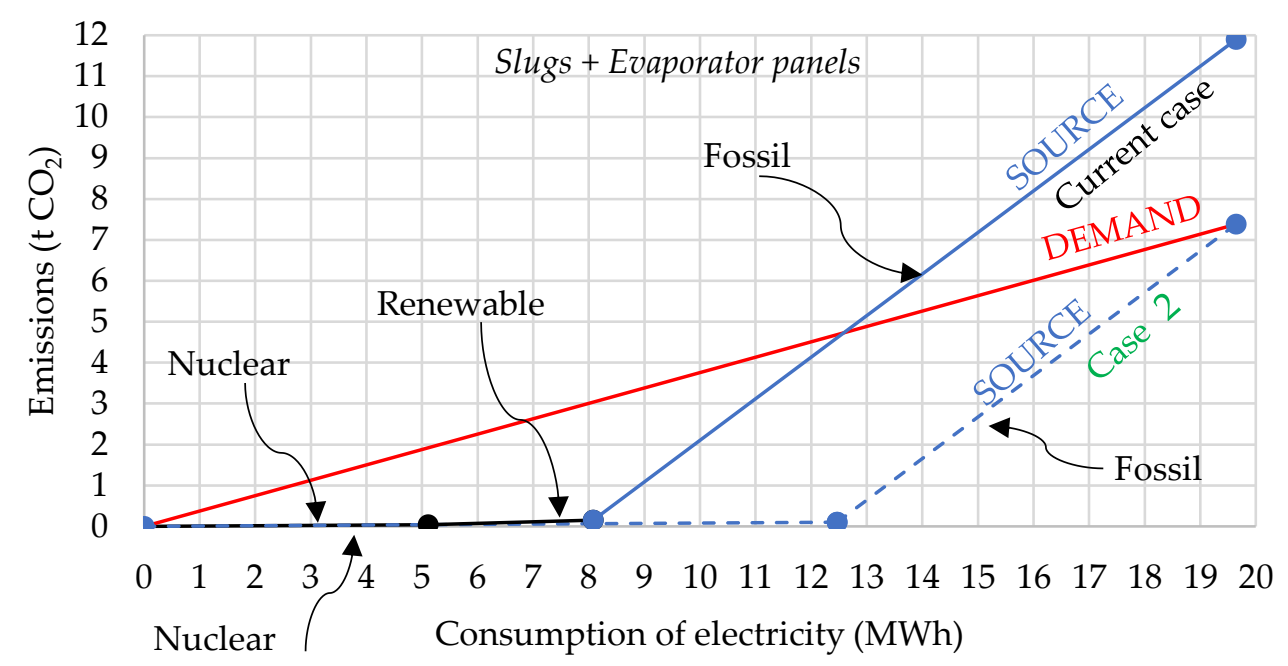

Figure 6. Pinch diagram for Case 2 when electricity consumption is pinched for all the products combined.

\section{Conclusions}

In this work, an extension of CEPA was developed and applied to the energy- and carbon-intensive aluminum industry. Graphical, algebraic and optimization-based approaches for CCEP were applied for the production of specific aluminum products, i.e., aluminum slugs and evaporator panels. Graphical and algebraic approaches determined the minimum amount of zero- and low-carbon energy sources required to achieve the specified emission limit. The transportation model was further applied 
to energy planning for two specific products to calculate the optimal electricity mix to reach the specified emission limit with minimum cost.

All the approaches yielded similar results; the first two showed that about 2.14 MWh of zero-carbon or 2.22 MWh of low-carbon, and the same amounts of excess energy (2.14 MWh or 2.22 MWh), are obtained for $1 \mathrm{t}$ of aluminum slugs. The third approach was based on cost optimization and showed that $26 \%$ higher electricity cost would be required to achieve the specified $\mathrm{CO}_{2}$ emission target compared to the current case. In principle, this incremental cost can potentially be covered by economic incentives such as an emissions tax. CCEP can thus be used in the future to estimate the amount of such incentives needed to drive industrial fossil-based GHG emissions abatement.

Each approach showed its strengths and weaknesses, as summarized in Table 8. The graphical and algebraic approaches proved to be powerful tools for energy planning of industrial products, since they are intuitive and provide better insights into the problem for both analysis and communication. Optimization-based results are less intuitive; however, optimization automates the procedure and could include more details, including cost optimization. Hybrid approaches are suggested which combine different methods to yield the synergistic advantages of each separate method [63].

Table 8. Comparison of the approaches.

\begin{tabular}{|c|c|c|}
\hline Approach & Strengths & Weaknesses \\
\hline Graphical & $\begin{array}{l}\text { - useful approach for preliminary planning } \\
\text { - enables graphical (visual) presentation } \\
\text { - useful for communication of results } \\
\text { - enables user control } \\
\text { - enables verification of results }\end{array}$ & $\begin{array}{c}\text { - limited to simple problems } \\
\text { - limited accuracy of results } \\
\text { - size and unit dependence } \\
\text { - not flexible } \\
\text { - procedure is not automated } \\
\text { - cannot include details and objectives, } \\
\text { such as cost optimization }\end{array}$ \\
\hline Algebraic & $\begin{array}{l}\text { - application to both simple } \\
\text { and complex problems } \\
\text { - precision of results } \\
\text { - more systematic approach } \\
\text { - provides insight into the problem } \\
\text { - useful for communication of results }\end{array}$ & $\begin{array}{l}\text { - size and unit dependence } \\
\text { - not flexible } \\
\text { - procedure is not automated } \\
\text { - cannot include details and objectives, } \\
\text { such as cost optimization }\end{array}$ \\
\hline Optimization & $\begin{array}{c}\text { - application to both simple } \\
\text { and complex problems } \\
\text { - precision of results } \\
\text { - flexible } \\
\text { - automated procedure } \\
\text { - equations can be modified } \\
\text { - could include more details } \\
\text { and various objectives } \\
\text { - relatively simple input/code determination }\end{array}$ & $\begin{array}{c}\text { - requires background of } \\
\text { mathematical modeling } \\
\text { - more difficult communication of results } \\
\text { - verification of results is } \\
\text { less straightforward }\end{array}$ \\
\hline
\end{tabular}

This work demonstrated the usefulness of CCEP approaches in the move towards a more sustainable aluminum industry. Since aluminum is widely used in various applications and is highly energy intensive, optimizing the electricity supply mix used in its production could significantly contribute to conserving resources and decreasing the global carbon footprint. However, regarding the optimization of the electricity mix, more detailed exploration regarding the electricity sector should be performed in terms of the cost, emissions, sustainability and availability of low-, zero- and negative-carbon emission sources.

In the future, CCEP analyses will be extended for targeting GHG $\left(\mathrm{CO}_{2}\right.$ Equation emissions) and other footprints. Various options for carbon capture could be incorporated, including technologies to achieve GHG emissions reductions. Additionally, $\mathrm{CO}_{2}$ emissions reductions could be analyzed by including mass integration to minimize emissions and the use of materials. Analyses could also be expanded to more aluminum products and to include more details regarding types of energy sources 
(renewable energy could be separated to hydro, photovoltaics, geothermal, wind, biomass, etc.), and their availability and pricing (e.g., hourly based), including future prices. Multiscale application of PI techniques could be used to improve material and energy efficiency to reduce energy consumption and emissions at the process, TS and supply chain network levels [33]. The methodology will be extended to account for variations in the ratio of primary and secondary aluminum within a circular economy framework and to account for negative emission technologies, and will include the combined use of all three proposed approaches.

Author Contributions: R.G., L.Č. and Z.K.: conceptualization and methodology; R.G.: data curation, formal analysis, and original draft preparation; L.Č.: resources and supervision; L.Č., M.H., R.R.T. and Z.K.: writing-review and editing. All authors have read and agreed to the published version of the manuscript.

Funding: The authors are grateful for funding support from the companies Talum d.d. and Talum Inštitut d.o.o. and from the Slovenian Research Agency (research core funding No. P2-0412 and P2-0032 and projects N2-0138 and J7-1816).

Conflicts of Interest: The authors declare no conflict of interest.

\section{Abbreviations}

$\begin{array}{ll}\text { CCEP } & \text { Carbon-constrained energy planning } \\ \text { CEPA } & \text { Carbon Emission Pinch Analysis } \\ \text { ETS } & \text { Emissions Trading System } \\ \text { EU } & \text { European Union } \\ \text { GHG } & \text { Greenhouse gas } \\ \text { LP } & \text { Linear Program } \\ \text { MP } & \text { Mathematical Programming } \\ \text { OBJ } & \text { objective function } \\ \text { PA } & \text { Pinch Analysis } \\ \text { PI } & \text { Process Integration } \\ \text { TS } & \text { Total Site }\end{array}$

\section{References}

1. Fan, Y.V.; Tan, R.R.; Klemeš, J.J. A system analysis tool for sustainable biomass utilisation considering the Emissions-Cost Nexus. Energy Convers. Manag. 2020, 210, 112701. [CrossRef]

2. Climate Watch. Global Historical GHG Emissions (Data Source: CAIT). Available online: Climatewatchdata. org/ghg-emissions?breakBy=sector\&chartType=percentage\&source $=71$ (accessed on 4 April 2020).

3. European Commission. 2030 Climate \& Energy Framework. Available online: Ec.europa.eu/clima/policies/ strategies/2030_en\#tab-0-0 (accessed on 4 April 2020).

4. European Commission. EU Emissions Trading System (EU ETS). Available online: Ec.europa.eu/clima/ policies/ets_en (accessed on 8 February 2020).

5. European Commission. Commission delegated regulation (EU) 2019/331 of 19 December 2018 determining transitional Union-wide rules for harmonised free allocation of emission allowances pursuant to Article 10a of Directive 2003/87/EC of the European Parliament and of the Council. Off. J. Eur. Union Bruss. 2019, 59, 25.

6. Primary Aluminium Smelting Energy Intensity. Available online: World-aluminium.org/statistics/primaryaluminium-smelting-energy-intensity (accessed on 23 January 2020).

7. European Commission. Electricity Production, Consumption and Market Overview. Available online: Ec.europa.eu/eurostat/statistics-explained/index.php/Electricity_production,_consumption_and_market_ overview\#Electricity_generation (accessed on 8 February 2020).

8. Lee, J.-Y.; Lin, H.-F. Multi-Footprint Constrained Energy Sector Planning. Energies 2019, 12, 2329. [CrossRef]

9. Akyüz, E. Advantages and disadvantages of nuclear energy in Turkey: Public perception. Eurasian J. Environ. Res. 2017, 1, 1-11.

10. Petrescu, F.I.; Apicella, A.; Petrescu, R.V.; Kozaitis, S.; Bucinell, R.; Aversa, R.; Abu-Lebdeh, T. Environmental protection through nuclear energy. Am. J. Appl. Sci. 2016, 13, 941-946. [CrossRef] 
11. Tan, R.R.; Sum Ng, D.K.; Yee Foo, D.C. Pinch analysis approach to carbon-constrained planningfor sustainable power generation. J. Clean. Prod. 2009, 17, 940-944. [CrossRef]

12. Tan, R.R.; Foo, D.C. Pinch analysis approach to carbon-constrained energy sector planning. Energy 2007, 32, 1422-1429. [CrossRef]

13. Foo, D.C.; Tan, R.R.; Ng, D.K. Carbon and footprint-constrained energy planning using cascade analysis technique. Energy 2008, 33, 1480-1488. [CrossRef]

14. Ooi, R.E.H.; Foo, D.C.Y.; Tan, R.R. Targeting for carbon sequestration retrofit planning in the power generation sector for multi-period problems. Appl. Energy 2014, 113, 477-487. [CrossRef]

15. Tan, R.R.; Foo, D.C.Y.; Aviso, K.B.; Ng, D.K.S. The use of graphical pinch analysis for visualizing water footprint constraints in biofuel production. Appl. Energy 2009, 86, 605-609. [CrossRef]

16. Walmsley, M.R.W.; Walmsley, T.G.; Atkins, M.J.; Kamp, P.J.J.; Neale, J.R.; Chand, A. Carbon Emissions Pinch Analysis for emissions reductions in the New Zealand transport sector through to 2050. Energy 2015, 92, 569-576. [CrossRef]

17. Tan, R.R.; Aviso, K.B.; Foo, D.C.Y. Carbon emissions pinch analysis of economic systems. J. Clean. Prod. 2018, 182, 863-871. [CrossRef]

18. Pękala, Ł.M.; Tan, R.R.; Foo, D.C.Y.; Jeżowski, J.M. Optimal energy planning models with carbon footprint constraints. Appl. Energy 2010, 87, 1903-1910. [CrossRef]

19. Tan, R.R.; Aviso, K.B.; Foo, D.C. P-graph and Monte Carlo simulation approach to planning carbon management networks. Comput. Chem. Eng. 2017, 106, 872-882. [CrossRef]

20. Mu, P.; Yang, Y.; Han, Y.; Gu, X.; Zhu, Q. Raw material management networks based on an improved P-graph integrated carbon emission pinch analysis (CEPA-P-graph) method. Can. J. Chem. Eng. 2020, 98, 676-689. [CrossRef]

21. Klemeš, J.J. Handbook of Process Integration (PI): Minimisation of Energy and Water Use, Waste and Emissions; Woodhead Publishing Limited: Cambridge, UK, 2013.

22. Linnhoff, B.; Flower, J.R. Synthesis of heat exchanger networks: I. Systematic generation of energy optimal networks. AIChE J. 1978, 24, 633-642. [CrossRef]

23. Dhole, V.R.; Linnhoff, B. Total site targets for fuel, co-generation, emissions, and cooling. Comput. Chem. Eng. 1993, 17, S101-S109. [CrossRef]

24. Colmenares, T.R.; Seider, W.D. Heat and power integration of chemical processes. AIChE J. 1987, 33, 898-915. [CrossRef]

25. El-Halwagi, M.M.; Manousiouthakis, V. Synthesis of mass exchange networks. AIChE J. 1989, 35, $1233-1244$. [CrossRef]

26. Alves, J.J.; Towler, G.P. Analysis of Refinery Hydrogen Distribution Systems. Ind. Eng. Chem. Res. 2002, 41, 5759-5769. [CrossRef]

27. Zhelev, T.; Ntlhakana, J. Energy-environment closed-loop through oxygen pinch. Comput. Chem. Eng. 1999, 23, S79-S83. [CrossRef]

28. Singhvi, A.; Shenoy, U. Aggregate planning in supply chains by pinch analysis. Chem. Eng. Res. Des. 2002, 80, 597-605. [CrossRef]

29. Foo, D.C.Y.; Kazantzi, V.; El-Halwagi, M.M.; Manan, Z.A. Surplus diagram and cascade analysis technique for targeting property-based material reuse network. Chem. Eng. Sci. 2006, 61, 2626-2642. [CrossRef]

30. Tjan, W.; Tan, R.R.; Foo, D.C. A graphical representation of carbon footprint reduction for chemical processes. J. Clean. Prod. 2010, 18, 848-856. [CrossRef]

31. Klemeš, J.J.; Varbanov, P.S.; Ocłon, P.; Chin, H.H. Towards Efficient and Clean Process Integration: Utilisation of Renewable Resources and Energy-Saving Technologies. Energies 2019, 12, 4092. [CrossRef]

32. Gai, L.; Varbanov, P.S.; Walmsley, T.G.; Klemeš, J.J. Critical Analysis of Process Integration Options for Joule-Cycle and Conventional Heat Pumps. Energies 2020, 13, 635. [CrossRef]

33. Jamaluddin, K.; Wan Alwi, S.R.; Abdul Manan, Z.; Hamzah, K.; Klemeš, J.J. A Process Integration Method for Total Site Cooling, Heating and Power Optimisation with Trigeneration Systems. Energies 2019, 12, 1030. [CrossRef]

34. Bütün, H.; Kantor, I.; Maréchal, F. Incorporating Location Aspects in Process Integration Methodology. Energies 2019, 12, 3338. [CrossRef]

35. Chen, Y.; Zhu, J. A Graph Theory-Based Method for Regional Integrated Energy Network Planning: A Case Study of a China-US Low-Carbon Demonstration City. Energies 2019, 12, 4491. [CrossRef] 
36. Yap, J.Y.; Tan, J.; Foo, D.C.; Tan, R.R.; Papadokonstantakis, S.; Badr, S. A graphical method for carbon dioxide emissions reduction in multi-product plants. Process Saf. Environ. Prot. 2020, 133, 51-63. [CrossRef]

37. Qin, Z.; Tang, K.; Wu, X.; Yu, Y.; Zhang, Z. Product-based Carbon Constraint Energy Planning with pinch analysis for sustainable methanol industry in China. Chem. Eng. Trans. 2017, 61, 103-108.

38. Sinha, R.K.; Chaturvedi, N.D. A graphical dual objective approach for minimizing energy consumption and carbon emission in production planning. J. Clean. Prod. 2018, 171, 312-321. [CrossRef]

39. Abdul Aziz, E.; Wan Alwi, S.R.; Lim, J.S.; Abdul Manan, Z.; Klemeš, J.J. An integrated Pinch Analysis framework for low $\mathrm{CO}_{2}$ emissions industrial site planning. J. Clean. Prod. 2017, 146, 125-138. [CrossRef]

40. Sinha, R.K.; Chaturvedi, N.D. A review on carbon emission reduction in industries and planning emission limits. Renew. Sustain. Energy Rev. 2019, 114, 109304. [CrossRef]

41. Edenhofer, O.; Pichs-Madruga, R.; Sokona, Y.; Minx, J.C.; Farahani, E.; Kadner, S.; Seyboth, K.; Adler, A.; Baum, I.; Brunner, S.; et al. Climate Change 2014: Mitigation of Climate Change; Cambridge University Press: New York, NY, USA, 2015; Volume 3.

42. Zhang, Y.; Sun, M.; Hong, J.; Han, X.; He, J.; Shi, W.; Li, X. Environmental footprint of aluminum production in China. J. Clean. Prod. 2016, 133, 1242-1251. [CrossRef]

43. Emsley, J. Nature's Building Blocks: An A-Z Guide to the Elements; Aluminium or Aluminum (USA); Oxford University Press: New York, NY, USA, 2011.

44. Durković, V.; Đurišić, Ž. Analysis of the potential for use of floating PV power plant on the Skadar Lake for electricity supply of aluminium plant in Montenegro. Energies 2017, 10, 1505. [CrossRef]

45. Ministry of Infrastructure of the Republic of Slovenia. Energy Balance for the Republic of Slovenia for 2017. Available online: Energetika-portal.si/fileadmin/dokumenti/publikacije/energetska_bilanca/ebrs_2017.pdf (accessed on 22 April 2020). (In Slovenian)

46. Salonitis, K.; Jolly, M.; Pagone, E.; Papanikolaou, M. Life-Cycle and Energy Assessment of Automotive Component Manufacturing: The Dilemma between Aluminum and Cast Iron. Energies 2019, 12, 2557. [CrossRef]

47. Gomilšek, R.; Čuček, L.; Homšak, M.; Kravanja, Z. Towards GHG Emissions Neutrality of Aluminium Slug Production: An Industrial Study. Chem. Eng. Trans. 2019, 76, 217-222.

48. Haraldsson, J.; Johansson, M.T. Energy efficiency in the supply chains of the aluminium industry: The cases of five products made in Sweden. Energies 2019, 12, 245. [CrossRef]

49. Tan, R.R.; Aviso, K.B.; Foo, D.C. P-Graph Approach to Carbon-Constrained Energy Planning Problems. In Computer Aided Chemical Engineering; Elsevier: Amsterdam, The Netherlands, 2016; Volume 38, pp. 2385-2390.

50. Crilly, D.; Zhelev, T. Emissions targeting and planning: An application of $\mathrm{CO}_{2}$ emissions pinch analysis (CEPA) to the Irish electricity generation sector. Energy 2008, 33, 1498-1507. [CrossRef]

51. Atkins, M.J.; Morrison, A.S.; Walmsley, M.R. Carbon emissions pinch analysis (CEPA) for emissions reduction in the New Zealand electricity sector. Appl. Energy 2010, 87, 982-987. [CrossRef]

52. Walmsley, M.R.; Walmsley, T.G.; Atkins, M.J. Achieving 33\% renewable electricity generation by 2020 in California. Energy 2015, 92, 260-269. [CrossRef]

53. Jia, X.; Li, Z.; Wang, F.; Foo, D.C.; Tan, R.R. Multi-dimensional pinch analysis for sustainable power generation sector planning in China. J. Clean. Prod. 2016, 112, 2756-2771. [CrossRef]

54. Salman, B.; Nomanbhay, S.; Foo, D.C. Carbon emissions pinch analysis (CEPA) for energy sector planning in Nigeria. Clean Technol. Environ. Policy 2019, 21, 93-108. [CrossRef]

55. Baležentis, T.; Štreimikienè, D.; Melnikienė, R.; Zeng, S. Prospects of green growth in the electricity sector in Baltic States: Pinch analysis based on ecological footprint. Resour. Conserv. Recycl. 2019, 142, 37-48. [CrossRef]

56. Su, W.; Ye, Y.; Zhang, C.; Baležentis, T.; Štreimikienè, D. Sustainable energy development in the major power-generating countries of the European Union: The Pinch Analysis. J. Clean. Prod. 2020, 256, 120696. [CrossRef]

57. Andiappan, V.; Foo, D.C.; Tan, R.R. Process-to-Policy (P2Pol): Using carbon emission pinch analysis (CEPA) tools for policy-making in the energy sector. Clean Technol. Environ. Policy 2019, 21, 1383-1388. [CrossRef]

58. Lee, S.C.; Sum Ng, D.K.; Yee Foo, D.C.; Tan, R.R. Extended pinch targeting techniques for carbon-constrained energy sector planning. Appl. Energy 2009, 86, 60-67. [CrossRef]

59. Manan, Z.A.; Tan, Y.L.; Foo, D.C.Y. Targeting the minimum water flow rate using water cascade analysis technique. AIChE J. 2004, 50, 3169-3183. [CrossRef] 
60. Klemeš, J.J.; Kravanja, Z. Forty years of heat integration: Pinch analysis (PA) and mathematical programming (MP). Curr. Opin. Chem. Eng. 2013, 2, 461-474. [CrossRef]

61. Čuček, L.; Boldyryev, S.; Klemeš, J.J.; Kravanja, Z.; Krajačić, G.; Varbanov, P.S.; Duić, N. Approaches for retrofitting heat exchanger networks within processes and Total Sites. J. Clean. Prod. 2019, 211, 884-894. [CrossRef]

62. Cerda, J.; Westerberg, A.W.; Mason, D.; Linnhoff, B. Minimum utility usage in heat exchanger network synthesis A transportation problem. Chem. Eng. Sci. 1983, 38, 373-387. [CrossRef]

63. Fraser, D.M. Retrofit Mass Integration of Acid Gas Removal Systems in Petrochemical Plants. In Handbook of Process Integration (PI); Klemeš, J.J., Ed.; Woodhead Publishing Limited: Cambridge, UK, 2013; pp. 725-751.

(C) 2020 by the authors. Licensee MDPI, Basel, Switzerland. This article is an open access article distributed under the terms and conditions of the Creative Commons Attribution (CC BY) license (http://creativecommons.org/licenses/by/4.0/). 